\title{
HUBUNGAN PERSEPSI TERHADAP \\ KETERAMPILAN GURU MENGAJAR \\ DENGAN KONSENTRASI BELAJAR SISWA \\ DI MA DARUL KAROMAH RANDUAGUNG \\ SINGOSARI-MALANG
}

\author{
Khuzaimatul Latifah \\ Zainal Habib \\ Fakultas Psikologi \\ Universitas Islam Negeri (UIN) Maulana Malik Ibrahim Malang \\ Jl. Gajayana 50 Malang Telp. 0341-558916
}

\begin{abstract}
Abstrak : Penelitian ini bertujuan untuk mengetahui gambaran persepsi siswa terhadap keterampilan guru mengajar, mengetahui tingkat konsentrasi belajar siswa, serta untuk mengetahui adakah hubungan persepsi terhadap keterampilan guru mengajar dengan konsentrasi belajar siswa di MA Darul Karomah Randuagung Singosari Malang. Metode penelitian yang digunakan adalah paradigma kuantitatif dengan pendekatan korelasional. Sampel dalam penelitian ini adalah siswa MA Darul Karomah yang diambil 25\% dari jumlah populasi yaitu berjumlah 32 orang.Pengumpulan data menggunakan skala dengan teknik pengambilan sampel yaitu simple random sampling. Teknik analisa data untuk menguji validitas menggunakan rumus Product Moment dan untuk menguji reliabilitas menggunakan rumus Cronbach's Alpha dengan bantuan program komputer yaitu SPSS 16.0 for windows.
\end{abstract}

Kata kunci: Persepsi, Keterampilan Mengajar, Guru, Konsentrasi Belajar, Siswa

PSIKOISLAMIKA. Jurnal Psikologi Islam (JPI) copyright @ 2014 Laboratorium Penelitian, Kajian Psikologi Islam dan Penerbitan. Volume 11. Nomor 1, Tahun 2014

\section{PENDAHULUAN}

Pendidikan merupakan hal yang mutlak bagi setiap manusia dan tidak dapat dipisahkan dari kehidupan seseorang. Sekolah sebagai institusi pendidikan pada dasarnya bertujuan mempersiapkan siswa untuk memecahkan masalah kehidupan, pada masa sekarang dan masa yang akan datang dengan pengembangan potensi yang dimilikinya. Peningkatan kualitas pendidikan pada semua jenjang pendidikan di sekolah berkaitan erat dengan kualitas proses belajar mengajar yang dilakukan guru dan siswa. Inti dari proses pendidikan secara umum adalah guru mengajar, sedangkan inti dari proses pengajaran itu pada hakikatnya adalah siswa belajar.

Banyak faktor psikologis yang berpengaruh terhadap hasil belajar siswa.Pada kenyataannya bahwa faktor psikologis memberikan andil yang cukup besar dalam memberikan landasan dan kemudahan dalam upaya mencapai tujuan belajar secara optimal. Sebaliknya, tanpa kehadiran faktor psikologis, bisa jadi memperlambat proses belajar, bahkan dapat pula menambah kesulitan dalam mengajar. Faktor psikologis yang dikatakan memiliki peranan penting itu, dapat dipandang sebagai cara-cara berfungsinya pikiran siswa dalam hubungannya dengan pemahaman bahan pelajaran, sehingga penguasaan terhadap bahan yang disajikan lebih mudah dan efektif (Thomas Staton, dalam Sunhaji, 2009:16).

Salah satu faktor yang berpengaruh terhadap proses belajar siswa adalah kemampuan konsentrasi siswa. Kemampuan seseorang untuk berkonsentrasi penting pada saat belajar, maupun pada saat melaksanakan tugas-tugas yang diberikan. Berkaitan 
dengan itulah konsentrasi belajar siswa perlu memperoleh perhatian lebih agar siswa kelak mampu memperhatikan dan menyerap pelajaran yang diberikan oleh guru di dalam proses belajar mengajar (Marbun, 2012:1).

Konsentrasi belajar sangat dibutuhkan dalam proses belajar mengajar. Tanpa konsentrasi belajar, maka peristiwa belajar itu sesungguhnya tidak ada atau tidak berlangsung. Oleh karena itu setiap anak dalam mengikuti proses pembelajaran di sekolah diharapkan dapat berkonsentrasi dengan baik. Kemampuan anak dalam berkonsentrasi akan mempengaruhi kecepatan dalam menangkap materi yang diberikan oleh guru. Seorang anak yang mempunyai kemampuan baik dalam konsentrasi akan lebih cepat menangkap materi yang disampaikan guru pada proses pembelajaran daripada siswa yang mempunyai kemampuan konsentrasi kurang baik (Slameto, 2010:85).

Secara umum yang dimaksud dengan konsentrasi adalah kemampuan seseorang untuk bisa mencurahkan perhatian dalam waktu yang relatif lama. Sedangkan siswa dikatakan berkonsentrasi pada pelajaran jika dia bisa memusatkan perhatian pada apa yang dipelajarinya. Dengan berkonsentrasi, anak tidak mudah mengalihkan perhatian pada masalah lain di luar yang dipelajarinya (Slameto, 2012:86).

Salah satu tolak ukur keberhasilan dalam proses pembelajaran adalah adanya partisipasi aktif peserta didik dalam kegiatan belajar mengajar di kelas. Namun keberhasilan tersebut hingga saat ini masih sulit tercapai, selain sarana prasarana yang belum lengkap, juga disebabkan konsentrasi belajar yang relatif rendah. Hal demikian di atas yang terjadi di MA Darul Karomah Randuagung Singosari Malang. Berdasarkan pengamatan langsung yang dilakukan peneliti pada bulan Juli 2013 menunjukkan bahwa kondisi 5 kelas di sekolah tersebut cenderung tidak kondusif pada pelaksanaan kegiatan belajar mengajar yang mana dijumpai permasalahan yang dihadapi oleh siswa seperti siswa mengganggu teman sebangkunya dalam proses pembelajaran, siswa gelisah saat mengikuti proses pembelajaran, siswa tidak tenang dan tidak bisa memperhatikan guru dalam penyampaian bahan pelajaran, siswa tidak dapat menuntaskan tugas dengan baik, siswa melamun di dalam kelas, siswa tidur di dalam kelas, siswa tidak mengikuti instruksi guru dengan baik serta siswa tidak aktif dalam proses pembelajaran. Akibatnya berpengaruh pada nilai yang diperoleh oleh siswa pada tugas dan ulangan yang menunjukkan banyaknya siswa yang memperoleh nilai dibawah standart ketuntasan minimal sehingga siswa harus mengikuti ujian ulang atau remidi.

Perilaku tersebut dapat menggambarkan bahwa konsentrasi belajar siswa MA Darul Karomah Randuagung Singosari Malang relatif rendah karena berdasarkan indikator untuk mengukur konsentrasi siswa dalam belajar sebagaimana dikemukakan oleh Super dan Crities (dalam Rachman, 2010:1) bahwa cici-ciri siswa yang memiliki konsentrasi belajar yang tinggi adalah sebagai berikut: 1) Memperhatikan setiap materi pelajaran yang disampaikan guru, 2) Dapat merespon dan memahami setiap materi pelajaran yang diberikan, 3) Selalu bersikap aktif dengan bertanya dan memberikan argumentasi mengenai materi pelajaran yang disampaikan guru, 4) Menjawab dengan baik dan benar setiap pertanyaan yang diberikan guru, dan 5) Kondisi kelas tenang dan tidak gaduh saat menerima materi pelajaran.

Selain hasil observasi di atas, dari hasil wawancara dengan Huda selaku kepala sekolah menunjukkan bahwa siswa cenderung mencari alasan untuk tidak ikut pelajaran seperti permisi ke toilet, dan beberapa alasan lainnya. Selanjutnya Huda menambahkan bahwa kurangnya konsentrasi siswa pada kegiatan belajar mengajar yang ditandai dengan suasana kelas yang tidak kondusif seperti siswa berbicara sendiri dan tidak memperhatikan penjelasan guru merupakan indikasi bahwa siswa tidak memiliki niat pada kegiatan belajar tersebut. Huda juga mengungkapkan bahwa alasan siswa seperti itu karena mereka merasa pelajaran itu membosankan, guru yang menyampaikan materi tidak menarik, terlalu cepat dalam menjelaskan sehingga tidak ada motivasi dalam diri siswa untuk memperkaya pengetahuan mereka dengan materi yang disampaikan (Wawancara tanggal 27 Juli 2013).

Fakta-fakta di atas berhubungan dengan kondisi kegiatan belajar mengajar yang kurang diminati oleh siswa sehingga siswa tidak memperhatikan guru yang sedang mengajar. Hal ini berkaitan dengan persepsi siswa mengenai keterampilan guru mengajar. Berdasarkan hasil survey dengan sejumlah siswa MA Darul Karomah Randuagung Singosari Malang diperoleh hasil bahwasanya menurut mereka keterampilan mengajar guru yang baik dapat penulis rangkum dalam beberapa kriteria berikut: 1) Guru memiliki kemampuan dan terampil dalam mengkondisikan siswa serta mengatur kondisi kelas, 2) Guru memiliki kemampuan dan terampil dalam menggunakan metode pembelajaran yang sesuai 
dengan materi pelajaran, misalnya agar tidak menjenuhkan siswa diberi permainan edukatif, 3) Guru memiliki kompetensi psikomotor yang meliputi, keterampilan ekspresi verbal (pernyataan lisan) dan nonverbal (pernyataan tindakan) yang direfleksikan ketika mengelola proses mengajar-belajar. Dalam hal merefleksikan ekspresi verbal guru sangat diharapkan terampil dalam arti fasih dan lancar berbicara baik ketika menyampaikan uraian materi pelajaran maupun ketika menjawab pertanyaanpertanyaan siswa atau mengomentari sanggahan dan pendapat siswa. Mengenai keterampilan ekspresi nonverbal yang harus dikuasai guru ialah dalam hal mendemonstrasikan hal-hal yang terkandung dalam materi pelajaran, seperti kecakapan dalam menulis dan membuat bagan di papan tulis, memeragakan proses terjadinya sesuatu, memeragakan prosedur melakukan keterampilan praktis, selain itu siswa juga menyukai guru yang murah senyum, adil dan tidak pilih kasih, memiliki pengetahuan yang luas dan tidak mengandalkan buku bahan ajar, dan 4) Guru memiliki kemampuan dan terampil dalam memotivasi siswa agar tetap aktif mengikuti pelajaran selama proses belajar mengajar berlangsung hingga selesai.

Beberapa kriteria keterampilan mengajar guru menurut siswa MA Darul Karomah Randuagung Singosari Malang sebagaimana telah disebutkan diatas sejalan dengan pendapat Gagne(dalam Dahar, 2011:127) mengenai keterampilan dasar yang harus dimiliki guru saat mengajar yaitu meliputi: 1) keterampilan membuka pelajaran, 2) keterampilan mengadakan variasi, 3) keterampilan menjelaskan, 4) keterampilan mengelola kelas, 5)keterampilan membimbing pembelajaran perseorangan atau individual, dan 6) keterampilan menutup pelajaran.

Pada kegiatan belajar mengajar terdapat proses interaksi antara guru dan siswa yang menyebabkan munculnya suatu persepsi. Persepsi tersebut terjadi karena guru memberi stimulus berupa rangsangan yang dapat berupa cara menjelaskan, penampilan, cara berbicara, dan lain-lain. Persepsi sebagai salah satu faktor psikologis berpengaruh terhadap pencapaian prestasi belajar siswa. Siswa merupakan sasaran utama dalam proses belajar mengajar yang memiliki prestasi berbeda-beda dikarenakan karakter. Pada saat proses belajar mengajar seorang siswa diharapkan memiliki persepsi yang positif terhadap segala sesuatu yang menyangkut aktivitas belajar mengajar, salah satunya adalah persepsi terhadap guru (Yulianti, 2012:1).
Persepsi merupakan proses yang menyangkut masuknya pesan atau informasi ke dalam otak. Melalui persepsi manusia akan terus menerus mengadakan hubungan dengan lingkungannya melalui alat indera, yaitu indra penglihatan, pendengar, peraba, perasa, dan pencium (Slameto: 1995:102). Oleh karena itu, guru sebagai pendidik harus melengkapi dirinya dengan berbagai keterampilan yang diharapkan dapat membantu dalam menjalankan tugasnya dalam interaksi edukatif (Djamarah, 2005:99).

Persepsi siswa terhadap kemampuan guru berbeda-beda ditentukan karakteristik pribadi perilaku persepsi yang meliputi sikap, motif, minat, dan harapan.Faktor internal yang melekat dalam diri perilaku persepsi siswa adalah belajar karena merasa perlu untuk meningkatkan pengetahuan dan keterampilannya.Sebagai pelaku persepsi, siswa perlu diajak mampu berpikir logis dan rasional.Hal tersebut diperlukan agar memberikan kesan secara objektif dan tidak terlalu dipengaruhi oleh faktor internal saja yang bersumber pada keyakinan dan karakteristik kepribadian seseorang. Keilmuan yang dimiliki setiap guru juga harus berkualitas tinggi. Hal ini diperlukan agar guru mampu menyadarkan siswa terhadap adanya faktor eksternal yang bersumber dari situasi dan lingkungan melalui proses informasi yang dapat mempengaruhi persepsi. Selain itu guru seharusnya mampu mencairkan suasana yang kontradiksi karena bervariasinya siswa.Syarat sebagai guru adalah kemampuan untuk melakukan komunikasi (Mahanani, 2013:1).

Persepsi siswa terhadap keterampilan guru mengajar merupakan salah satu faktor yang mempengaruhi konsentrasi belajar siswa pada kegiatan belajar mengajar.Peranan yang dapat dilakukan oleh seorang guru untuk meningkatkan efektifitas belajar siswa adalah meningkatan persepsi siswa terhadap kemampuan guru yang meliputi atensi dan ekspektasi (Gagne, dalam Dahar, 2011:131).

Berdasarkan deskripsi mengenai persepsi siswa terhadap keterampilan guru yang disebutkan oleh Gagne bahwa guru merupakan sosok yang memiliki peran yang penting dalam pembelajaran karena kemampuan guru dapat mempengaruhi persespi siswa dan dijelaskan bahwa persepsi tersebut merupakan salah satu faktor yang berpengaruh dalam kegiatan belajar mengajar yang mana konsentrasi belajar siswa juga merupakan faktor penting untuk menunjang kemampuan siswa dalam menerima pelajaran agar indikator keberhasilan pembelajaran dapat tercapai. Sedangkan yang terjadi di MA Darul Karomah Randuagung Singosari Malang tidak sesuai 
dengan teori yang dijelaskan oleh Gagne bahwa persepsi siswa terhadap keterampilan guru mengajar berhubungan dengan konsentrasi belajar siswa, yang ada di lapangan bahwasanya guru-guru yang mengajar telah menjalankan tugasnya sebagaimana indikator yang disebutkan oleh Gagne di atas dan sesuai dengan kriteria siswa berdasarkan hasil survey yang telah dilakukan sebelumnya, namun yang terjadi di lapangan konsentrasi belajar siswa justru relatif rendah.

\section{METODE}

Penelitian ini merupakan penelitian yang menggunakan pendekatan kuantitatif, karena penelitian ini mendasarkan diri pada perolehan hasil data yang berupa angka-angka yang selanjutnya dilakukan analisis secara statistik. Berdasarkan data yang ingin dikumpulkan maka jenis penelitian ini adalah penelitian deskriptif korelasional yaitu suatu penelitian yang bertujuan untuk menemukan ada tidaknya hubungan dan apabila ada, maka seberapa erat hubungan serta seberapa berarti atau tidak hubungan tersebut (Arikunto, 2006:12). Sampel dalam penelitian ini adalah siswa MA yang diambil 25\% dari jumlah populasi 128 orang yaitu berjumlah 32 orang. Pengumpulan data menggunakan skala dengan teknik pengambilan sampel yaitu simple random sampling. Teknik pengumpulan data yang digunakan adalah dengan skala yang disebarkan kepada subjek, serta dengan observasi dan wawancara..

\section{HASIL DAN PEMBAHASAN Gambaran Persepsi Keterampilan Guru Mengajar}

Leavitt (dalam Desmita, 2011:117), mengemukakan bahwa perception dalam pengertian sempit adalah penglihatan yaitu bagaimana cara seseorang melihat sesuatu, sedangkan arti luas, perception adalah pandangan, yaitu bagaimana seseorang memandang atau mengartikan sesuatu.Persepsi siswa terhadap keterampilan guru mengajar dapat diartikan sebagai pandangan atau tanggapan peserta didik dengan cara menyimpulkan informasi dan menafsirkan pesan berdasarkan pengalaman tentang kemampuan atau keterampilan yang berhubungan dengankompetensi seorang guru dalam proses belajar-mengajar di sekolah untuk mengembangkan potensi-potensi peserta didik dan mencapai suatu tujuan dalam pembelajaran yang didahului oleh proses penginderaan dalam suatu pemecahan masalah atau situasi sosial.
Berdasarkan hasil pengolahan data yang telah dilakukan terhadap variabel persepsi keterampilan guru mengajar, dapat diketahui gambaran persepsi siswa pada kategori skor baik sebesar 93,8\% dengan jumlah frekuensi 30 siswa, yang berpersepsi kurang baik sebesar 3,1\% dengan jumlah frekuensi 1 siswa dan 3,1\% dengan jumlah frekuensi 1 untuk siswa yang berpersepsi buruk.

Dari hasil analisis di atas menunjukkan bahwa sebagian besar siswa MA Darul Karomah Randuagung Singosari Malang yang menjadi responden penelitian memiliki persepsi yang baik terhadap keterampilan guru dalam mengajar.Penilaian yang baik tersebut memberikan arti bahwa guru $g u r u$ telah mampu mengajar dengan metode yang disukai oleh siswa. Guru mampu mengaplikasikan berbagai media pembelajaran dalam kegiatan belajar mengajar. Selain itu guru mampu mengkondisikan siswa baik memainkan peran sebagai seorang guru, pendidik, motivator, fasilitator maupun sebagai inspirator. Guru juga mampu menjadi orang tua yang baik di sekolah sebagai pengganti orang tua di rumah, oleh karena itu berdasarkan penilain tersebut siswa dapat menerima berbagai cara guru mengajar dengan metoe yang berbeda-beda namun mendapat penilaian yang sama baiknya sehingga mampu diterima oleh siswa. Guru terus melakukan pembaruan dalam metode mengajar, dengan demikian guru telah mampu menerapkan pembelajaran yang aktif, inovatif, kreatif dan menyenangkan.

Sebagaimana survey awal yang dilakukan oleh peneliti mengenai beberapa kriteria guru yang disenangi oleh siswa yang mana diantaranya adalah guru dapat memotivasi siswa untuk tetap fokus terhadap pelajaran, guru yang suka menyelingi dengan humor saat mengajar, guru yang mampu menjadi teman curhat sehingga siswa memiliki wadah untuk mengungkapkan kesulitan dan masalah yang dialami. Seorang guru merupakan ujung tombak keberhasilan kegiatan pembelajaran karena kualitas kegiatan pembelajaran yang dilakukan sangat bergantung pada perencanaan dan pelaksanaan proses pembelajaran yang dilakukan, sehingga berdasarkan penilaian siswa tersebut dapat menunjang tugas guru yang bukan semata-mata mengajar (teacher centered) tapi lebih kepada membelajarkan siswa (children centered).

Penilaian yang baik dari siswa terhadap guru berkaitan dengan ruang lingkup keguruan mengenai tugas yang berhubungan dengan membantu siswa mengatasi masalah dalam belajar khususnya, dan 
masalah-masalah pribadi yang berpengaruh terhadap keberhasilan belajarnya karena bagaimana sebenarnya proses belajar siswa di kelas sangat erat kaitannya dengan berbagai masalah di luar kelas yang sering kali bersifat nonakademik (Rusman, 2013:45).

\section{Tingkat Konsentrasi Belajar Siswa}

Konsentrasi belajar merupakan salah satu komponen penting yang menunjang siswa di ranah kognitif dalam mengikuti kegiatan belajar mengajar.Konsentrasi dalam belajar menunjukkan adanya minat dan motivasi siswa dalam mengikuti pelajaran. Konsentrasi dibutuhkan agar materi yang disampaikan oleh guru dapat dengan mudah dipahami dan dimengerti siswa, sehingga siswa yang memiliki konsentrasi belajar yang baik, dia akan bertanya ketika ada hal yang belum dipahami serta dapat aktif mengikuti pembelajaran.

Konsentrasi belajar menurut G. G. Neill Wright (dalam Gie, 1995: 138) adalah keterserapan dalam mata pelajaran yang sedang dipelajari sampai titik kebutaan dan ketulian terhadap semua hal lainnya.Artinya adalah kemampuan siswa untuk bisa mencurahkan perhatian dalam waktu yang relatif lama. Siswa dapat dikatakan berkonsentrasi pada pelajaran jika dia bisa memusatkan perhatian pada apa yang dipelajari. Dengan berkonsentrasi, siswa tidak mudah mengalihkan perhatian pada masalah lain di luar yang dipelajarinya. Neill menambahkan bahwa pemusatan pikiran atau konsentrasi adalah suatu kebiasaan dan oleh karenanya dapat dilatih oleh setiap orang yang bersungguh-sungguh ingin mencapainya.

Berdasarkan hasil perhitungan norma kategorisasi data yang diperoleh dari variabel konsentrasi belajar dapat diketahui bahwa konsentrasi belajar siswa MA Darul Karomah Randuagung Singosari Malang berada pada kategori sedang. Hal ini dapat dilihat pada skor sedang sebesar 59,4\% dengan jumlah frekuensi 19 siswa, sedangkan yang memiliki konsentrasi belajar yang tinggi sebesar $37,5 \%$ dengan jumlah frekuensi 12 siswa dan 3,1\% dengan jumlah frekuensi 1 untuk siswa yang memiliki konsentrasi belajar rendah.

Sesuai dengan hasil analisis di atas maka dapat disimpulkan bahwa sebagian besar konsentrasi belajar siswa MA Darul Karomah Randuagung Singosari Malang berada pada tingkat atau kategori sedang dengan nilai prosentase $59,4 \%$ dari 32 responden yang menjadi subjek penelitian. Dengan data tersebut mengindikasikan bahwa sebagian besar siswa cukup mampu memusatkan perhatian saat kegiatan belajar mengajar, siswa mendengarkan penjelasan guru, siswa terlibat cukup aktif dalam pembelajaran, siswa mampu bereksplorasi, dan siswa juga dapat menikmati pelajaran di kelas hingga usai.

Akan tetapi berdasarkan hasil wawancara dan observasi awal yang dilakukan oleh peneliti sebelum melakukan penelitian didapatkan bahwa siswa MA Darul Karomah memiliki konsentrasi belajar yang rendah, hal ini berdasarkan pada indikator yang dipaparkan oleh Super dan Crities pada bab sebelumnya. Hasil observasi menunjukkan bahwa tingkat konsentrasi siswa rendah yang ditandai oleh siswa tidak bisa memperhatikan guru dalam penyampaian bahan pelajaran, siswa tidak dapat menuntaskan tugas dengan baik, siswa melamun di dalam kelas, siswa tidur di dalam kelas, siswa tidak mengikuti instruksi guru dengan baik serta siswa tidak aktif dalam proses pembelajaran.

Perbedaan hasil observasi dengan data yang diperoleh saat ini sangat berbeda, dimana siswa cenderung memiliki tingkat konsentrasi belajar pada tingkat sedang yaitu $59,4 \%$ bahkan tinggi yaitu $37,5 \%$. Sebagaimana dijelaskan oleh Neill di atas bahwa konsentrasi dapat dilatih, maka kemungkinan siswa MA Darul Karomah Randuagung Singosari Malang telah melakukan latihan atau melatih kemampuan berkonsentrasi belajar di dalam kelas dengan baik sehingga menuai hasil yang nyata dalam kurun waktu yang tidak terlalu lama.

Perbedaan hasil penggalian data awal (observasi dan wawancara) dengan hasil analisa data ini bisa diartikan bahwa kategori sedang dan tinggi memiliki arti yang relative pada penelitian ini, karena siswa yang berada pada kategori sedang dan tinggi belum tentu dalam kenyataannya memiliki konsentrasi belajar yang tinggi juga.

Berdasarkan pemaparan di atas, adanya perbedaan tingkat konsentrasi siswa didasari oleh beberapa faktor yang mempengaruhi sebagaimana dikemukakan oleh Neill (dalam Gie 1995:79) yaitu faktor internal dan faktor eksternal, pada faktor internal meliputi faktor fisiologis seperti kelelahan, kemungkinan siswa berada pada kondisi fisik yang sehat berbeda dengan kondisi ketika pemeliti melakukan observasi terdahulu, kemudian faktor psikologis seperti motivasi, bakat minat, dan inteligensi, kemungkinan siswa telah mengetahui tujuan dari belajar sehingga siswa memiliki minat dan motivasi yang tinggi dalam mengikuti pelajaran. Sedangkan faktor eksternal meliputi keluarga, faktor kondisi sekolah yang mencakup kualitas guru, dan fasilitas sekolahnya.Semua hal tersebut memiliki 
andil dalam mempengaruhi konsentrasi belajar siswa baik secara signifikan maupun tidak. Selain itu perbedaan tersebut juga dipengaruhi oleh kondisi siswa yang memiliki gaya belajar yang beragam, dalam arti berbeda-beda. Jadi, perubahan tingkat konsentrasi belajar siswa saat ini sedikit banyak dipengaruhi berbagai faktor yang telah disebutkan di atas.

\section{Hubungan Persepsi terhadap Keterampilan Guru Mengajar dengan Konsentrasi Belajar Siswa di MA Darul Karomah Randuagung Singosari Malang}

Penelitian ini berdasar pada hasil observasi awal yang dilakukan oleh peneliti saat melaksanakan PKL di MA Darul Karomah Randuagung Singosari Malang. Berdasarkan hasil pengamatan peneliti pada kegiatan belajar mengajar peneliti melihat kondisi kelas yang kurang kondusif.Siswa tidak memusatkan perhatiannya pada guru yang mengajar pada saat itu dan hal tersebut terjadi tidak pada satu pelajaran dan satu kelas saja, namun cenderung pada semua kelas dan semua pelajaran dalam beberapa kali pertemuan.

Setelah melakukan pengamatan beberapa kali, peneliti menarik kesimpulan bahwa ada hal yang menarik untuk dilakukan penelitian, yaitu mengenai konsentrasi belajar siswa. Karena konsentrasi belajar merupakan salah satu aspek kognitif belajar bagi siswa untuk menerima dan memahami pelajaran. Melihat guru-guru yang mengajar saat itu sudah interaktif, dan seringkali berusaha mengkondisikan siswa serta suasana kelas, namun dalam waktu yang singkat sudah kembali menjadi gaduh kembali. Dari kejadian tersbut peneliti merasa perlu dilakukan penelitian mengenai maslah tersebut, siswa tidak mampu berkonsentrasi padahal guru sudah menajalankan tugasnya dengan baik berdasarkan indikator-indikator yang dijelaskan oleh Gagne pada bab sebelumnya.

Berdasarkan teori konsentrasi yang ditulis oleh Neill dijelaskan bahwa terdapat beberapa faktor yang mempengaruhi konsentrasi belajar yaitu, faktor internal dan faktor eksternal. Faktor internal meliputi dari pribadi siswa sendiri seperti: motivasi, minat, inteligensi dan kelelahan fisik, sedangkan dari faktor eksternal yaitu: dari lingkungan sekolah yang meliputi gedung sekolah, guru, maupun fasilitasnya. Jadi faktor rendahnya konsentrasi belajar yang paling dekat dengan kondisi belajar mengajar bisa dari faktor diri siswa maupun dari guru.apabila siswa memiliki motivasi dan minat dalam mengikuti pelajaran maka siswa tentu akan memperhatikan penjelasan guru karena pada saat mengajar guru interaktif dengan siswanya. Namun yang menjadi permasalahan adalah siswa tidak dapat berkonsentrasi selama belajar pada kegiatan belajar mengajar sedangkan guru interaktif ketika mengajar. Pada suatu kegiatan belajar mengajar terdapat interaksi antara guru dan murid yang memunculkan suatu persepsi, maka terdapat kemungkinan siswa memiliki penialaian yang berbeda-beda mengenai cara guru mengajar. Pemaparan di atas menjadi pedoman peneliti dalam melakukan penelitian untuk membuktikan adakah hubungan antara Persepsi terhadap Keterampilan Guru Mengajar dengan Konsentrasi Belajar Siswa di MA Darul Karomah Randuagung Singosari Malang.

Berdasarkan perhitungan statistik menggunakan product moment pada program SPSS 16.0 for windows, yang dapat dilihat pada tabel 4.11 dapat diketahui bahwa tidak terdapat hubungan antara persepsi terhadap keterampilan guru mengajar dengan konsentrasi belajar siswa yang ditunjukkan pada nilai signifikansi 0.264 lebih besar dari 0.05.

Tidak adanya hubungan antara kedua variabel di atas membuktikan bahwa hipotesis peneliti tidak diterima.Faktor yang mempengaruhi adalah setelah melakukan penelitian konsentrasi belajar subyek sudah meningkat.Pada awal penelitian ditemukan bahwa konsentrasi belajar siswa rendah namun setelah penelitian ternyata konsentrasi siswa meningkat menjadi sedang dan bahkan cenderung tinggi. Hal ini dapat dilihat pada tabel 4. 2 yang menunjukkan skor sedang sebesar 59,4\% dengan jumlah frekuensi 19 siswa, sedangkan yang memiliki konsentrasi belajar yang tinggi sebesar 37,5\% dengan jumlah frekuensi 12 siswa dan 3,1\% dengan jumlah frekuensi 1 untuk siswa yang memiliki konsentrasi belajar rendah.

Selain itu persepsi siswa terhadap keterampilan guru mengajar hampir keseluruhan mempersepsikan baik, artinya sesuai dengan survey awal yang dilakukan oleh peneliti bahwa guru sudah intaktif dan dapat mengkondisikan kelas dan siswanya dengan baik.Jadi, berdasarkan hal di atas faktor yang mempengaruhi rendahnya konsentrasi belajar siswa pada saat itu bukan dari faktor ketarampilan guru mengajar melainkan dari faktor yang lain, seperti faktor internal siswa misalnya motivasi. Rendahnya motivasi siswa yang menjadikan siswa merasa malas untuk mengikuti kegiatan belajar mengajar, sehingga yang harus dilakukan guru adalah membangkitkan terlebih dahulu motivasi 
siswa. Saat ini, siswa MA Darul Karomah Randuagung Singosari Malang memiliki konsentrasi belajar yang berada pada tingkat sedang dan bahkan sebagian besar yang lain memiliki konsentrasi belajar yang tinggi, sedangkan persepsi siswa terhadap keterampilan guru mengajar hampir keseluruhan dari subyek penelitian berpersepsi baik. Hal tersebut berimplikasi pada tidak terjadinya korelasi antara kedua variabel tersebut.

Dengan demikian dapat disimpulkan faktor yang mempengaruhi tidak adanya hubungan antar variabel dan juga termasuk dalam kekurangan penelitian yang dilakukan oleh peneliti adalah sebagai berikut:

1. Berkaitan dengan rentang waktu antara survey awal dengan pelaksaan penelitian dapat dikatakan terlalu jauh. Ada kemungkinan dalam kurun waktu tersebut siswa mulai melatih diri untuk memfokuskan perhatian pada kegiatan belajar mengajar, yang mana mengenai hal tersebut tidak diketahui oleh peneliti. Sehingga terdapat perubahan konsentrasi belajar siswa yang awalnya saat disurvey berada pada ketegori cenderung rendah namun setelah dilakukan penelitian berubah menjadi sedang dan cenderung tinggi. Perubahan tersebut kemungkinan merupakan salah satu faktor yang mempengaruhi tidak adanya hubungan antara variabel $X$ yaitu Persepsi terhadap Keterampilan Guru Mengajar dengan variabel $Y$ yaitu Konsentrasi Belajar Siswa.

2. Berkaitan dengan penyebaran skala yang kurang merata pada subyek yang menjadi sampel penelitian. Faktor yang mempengaruhi adalah siswa kelas XII telah mengikuti UN sehingga ketika peneliti akan melakukan penelitian (menyebar skala) banyak siswa yang tidak masuk sekolah walaupun ada 2 siswa kelas XII yang secara kebetulan berada di sekolah. Selain itu penyebaran skala juga tidak merata

\section{DAFTAR PUSTAKA}

Arikunto, Suharsini. 2006. Prosedur Penelitian Suatu Pendekatan Praktek, Edisi Revisi ke-VI. Jakarta : PT. Rineka Cipta. Dahar, Ratna Wilis. 2011. Teori-teori Belajar dan Pembelajaran. Jakarta: Penerbit Erlangga.

Desmita. 2011.Psikologi Perkembangan Peserta Didik. Bandung: PT. Remaja Rosdakarya. pada perwakilan sampe tiap kelasnya yaitu baik pada kelas $\mathrm{X}$ maupun pada kelas XI. 3 . Pada skala yang peneliti sebarkan tertulis data identitas yang diantaranya peneliti meminta subyek untuk mengisi namanya. Hal tersebut memungkinkan subyek melakukan facking good atau facking bad dalam mengisi skala. Subyek merasa kurang aman dan mungkin merasa malu ketika jawaban-jawaban skala tersebut diketahui pemiliknya karena peneliti melakukan penelitian terhadap persepsi subyek pada keterampilan guru mengajar dan subyek juga diminta untuk menilai dirinya berkaitan dengan konsentrasi belajar, meskipun subyek tidak mengetahui apa yang diukur dalam skala tersebut ada kemungkinan subyek merasa takut untuk jujur dalam memberikan jawaban pada pernyataan-pernyataan yang tersedia dalam skala.

\section{KESIMPULAN}

Berdasarkan hasil penelitian menunjukkan bahwa gambaran persepsi siswa tehadap keterampilan guru mengajar adalah baik dengan prosentase $93,8 \%$. Tingkat konsentrasi belajar siswa sebagian besar berada pada taraf sedang dengan prosentase $59,4 \%$. Analisa data menggunakan product moment diperoleh nilai rxy $=0,204 ; \operatorname{sig}=0,264>0,05$. Hasil analisa menunjukkan bahwa tidak ada hubungan antara Persepsi terhadap Keterampilan Guru Mengajar dengan Konsentrasi Belajar Siswa MA Darul Karomah Randuagung Singosari Malang. Hal ini ditunjukkan dengan perhitungan, diketahui bahwa rxy =0,204, dengan nilai signifikansi sebesar 0,264 yang artinya Hipotesis alternatif $(\mathrm{Ha})$ ditolak. Hal ini dapat dilihat dari rxy $=0.204$ lebih besar dari $a>0.05$ dan sign $=0.264$ lebih besar dari $p=0.05$, artinya adalah tidak terdapat hubungan antara Persepsi terhadap Keterampilan Guru Mengajar dengan Konsentrasi Belajar Siswa MA.

Djamarah, Syaiful Bahri. 2000. Guru dan Anak Didik dalam Interaksi Edukatif. Jakarta: PT. Rineka Cipta.

Djamarah, Syaiful Bahri. 2013. Strategi Belajar Mengajar. Jakarta: PT. Rineka Cipta.

Mahanani, Pelopor Pendidikan. 2013. Peranan Guru dalam Meningkatkan EfektivitasBelajar. Diakses tanggal 03 Februari 2014dari: (http:// www.m- edukasi.web.id/2013/01/peranan- 
guru-dalam- meningkatkan. html) Muhaimin. 2002. Paradigma Pendidikan Islam Upaya Meningkatkan Pendidikan Agama Islamdi Sekolah. Bandung: PT. Remaja Rosdakarya.

Rusman. 2013. Model-model Pembelajaran. Jakarta: PT Raja Grafindo Persada. Sardiman. 2007. Interaksi dan Motivasi Belajar Mengajar. Jakarta: Raja Grafindo Persada. Sunhaji. 2009. Strategi Pembelajaran. Yogyakarta: Grafindo Litera Media.
Slameto. 2010. Belajar dan Faktor- Faktor yang Mempengaruhinya. Jakarta: Rineka Cipta. Syah, Muhibbin. 2010. Psikologi Pendidikan. Bandung: PT Remaja Rosdakarya. Winkel, W.S. 2014. Psikologi Pengajaran. Yogyakarta: Sketsa.

Yulianti, Resti Kurnia. 2012. Persepsi Siswa Kelas X TKJ Tentang Kemampuan Mengajar Guru Mata Pelajaran IPPK di SMK Tamansiswa Jetis Yogyakarta. 